The University of San Francisco

USF Scholarship: a digital repository @ Gleeson Library |

Geschke Center

Public and Nonprofit Administration

School of Management

1992

\title{
Philanthropic Dimensions of Mutual Benefit Organizations
}

\author{
Michael O'Neill \\ University of San Francisco, oneill@usfca.edu
}

Follow this and additional works at: http://repository.usfca.edu/pna

Part of the Nonprofit Administration and Management Commons

\section{Recommended Citation}

O’Neill, M. (1992). Philanthropic dimensions of mutual benefit organizations. Working paper (University of San Francisco. Institute for Nonprofit Organization Management); no. 18. San Francisco, CA: Institute for Nonprofit Organization Management, College of Professional Studies, University of San Francisco.

This Other is brought to you for free and open access by the School of Management at USF Scholarship: a digital repository @ Gleeson Library | Geschke Center. It has been accepted for inclusion in Public and Nonprofit Administration by an authorized administrator of USF Scholarship: a digital repository@ Gleeson Library | Geschke Center. For more information, please contact repository@usfca.edu. 
Philanthropic Dimensions of Mutual Benefit organizations

by Michael O'Neill

Working Paper No. 18

working papers

University of San Francisco

College of Professional Studies 
Philanthropic Dimensions of Mutual Benefit Organizations

by Michael O'Neill

Working Paper No. 18

For Further Information Contact:

April, 1992

Institute for Nonprofit Organization Management

College of Professional Studies

Oniversity of San Francisco

2130 Fulton Street

San Francisco, CA 94117-1080

(415) $666-6867$ 


\title{
Philanthropic Dimensions of Mutual Benefit Organizations
}

\author{
Michael O'Neill \\ University of San Francisco
}

It is curious that the 400,000 mutual benefit organizations (MBOs) in the United States are almost completely ignored by nonprofit sector scholars, since these organizations not only are interesting in their own right but also include a great deal of charitable activity and may well represent the most ancient and fundamental form of philanthropy. Powell's The Nonprofit Sector: A Research Handbook (1987) contains only seven passing references to MBOs.' The Foundation Center's two recent bibliographies with a total of 6,802 entries include no references to MBOs or

\footnotetext{
1The two most detailed references both dismiss the philanthropic significance of MBOs:

Mutual benefit organizations range from elitist social clubs to trade unions. In many ways these are closer to the forprofit sector than to the philanthropic. There is frequently very iittle altruism about the motivation of their members. They differ from the typical commercial forprofit enterprise in providing goods or services for their members collectively rather than on a quid pro quo transaction basis, which usually is why the nonprofit form is adopted ( $p$. 51).
}

In Ring I are the noncharitable nonprofits that are listed throughout the succeeding subsections of the exemption statute, in [Internal Revenue Code sections] 501 (c) (4)-(21); here we have social clubs, veterans' organizations, labor unions, burial societies, chambers of commerce, marketing cooperatives, and other associations that may roughly be described as carrying forward the private interests of the members but subject to the nondistribution constraint ( $p$. 69, emphasis in the original). 
any similar term² (Derrickson, 1989; Derrickson and Kurdylo, 1990). Layton's bibliography (1987) with 1,614 entries includes no such references. The $150+$ working papers from Yale's Program on Non-Profit Organizations include none on nonprofit MBOs. Independent Sector's six volumes of Research in Progress from 1983 to 1988 contain no such references. The seven-volume Filer Commission Report of the mid-1970s contains no direct discussion of MBOs.

This is all the more remarkable in that there is a long tradition of sociological, anthropological, historical, and political science literature on voluntary associations, many of which fall into the MBO category and many of which have been consistently shown not only to have important member-benefit functions but also to contain philanthropic dimensions. Peter Dobkin Hall and others have remarked that the new field of nonprofit studies is already in danger of cutting itself adrift from the mainstream of more established disciplines; the general disregard of MBOs by nonprofit sector scholars may be a case in point.

The primary, member-benefit functions of MBOs have been detailed by scholars from a variety of disciplines. ${ }^{3}$ This paper will focus on the secondary but important philanthropic functions

\footnotetext{
2 "Mutual benefit organizations," "mutual assistance associations," "fraternal [benefit] organizations, " friendly societies," "self-help groups."

${ }^{3}$ Still the best place to start is Smith and Freedman's Voluntary Associations: Perspectives on the Literature (1972).
} 
of MBOs and will argue that MBOs merit much more attention than they currently receive from serious students of philanthropy.

\section{Definitional Issues}

For the purposes of this discussion, we will accept the American Bar Association's division of the nonprofit sector into "public benefit," "religious," and "mutual benefit" corporations (Revised, 1988). The first two categories are essentially those designated by the Internal Revenue Service and most states as organizations established for "religious, charitable, scientific, - . Iiterary, or educational purposes. . ." They are the nonprofits categorized by most scholars and governmental bodies as "charitable" or "philanthropic" and are the organizations termed "the independent sector" by the national organization of that name (Hodgkinson and weitzman, 1984, p. 14; and subsequent reports). The "noncharitable," "nonphilanthropic, " non"independent sector" nonprofits are the mutual benefit organizations.

The American Bar Association describes rather than defines mutual benefit organizations:

Trade associations, social clubs and fraternal organizations are typical examples of mutual benefit corporations. Mutual benefit corporations hold themselves out as benefitting, representing and serving a group of individuals or entities. 
Those individuals or entities are usually referred to as "members." (Revised, p. xxviii)

Principal types of MBOs include labor unions, agricultural groups, business leagues, chambers of commerce, social and recreation clubs, fraternal beneficiary societies, pension funds, burial associations, credit unions, cooperative purchasing associations, and self-help groups of many types. "The largest single type is that of fraternal associations, numbering about 120,000 of the $400,000 \mathrm{MBOS}$ registered with the IRS. ${ }^{5}$

As has often been noted, "philanthropy" comes from the Greek verb phileo, to love, and the Greek noun anthropos, a human being, humankind las distinguished from aner, andros, a male person). Webster's defines "philanthropy" as "goodwill to fellowmen;. . . active effort to promote human welfare." The Oxford English Dictionary defines "philanthropy" as "love to

\footnotetext{
${ }^{4} \mathrm{Blau}$ and Scott (1962, p. 43) include "religious sects" among MBOs. Smith (1989) argues for recognition of a "membership sector," roughly equivalent to the world of $\mathrm{MBOs}$ and including religious organizations. The standard Industrial Classification codes include "religious organizations" (8660) as a subcategory of "membership organizations" (8600). Biddle (1992) estimates that 70 per cent of religion's revenue goes to member-benefit as distinguished from public-benefit purposes. Not only religion but virtually every type of 501 (c) (3) would, upon closer analysis, reveal member-benefit as well as public-benefit dimensions. All of which suggests that the division of nonprofits into two or three large groups-- "mutual benefit" and "public benefit," sometimes. including "religious"--may be at least as misleading as it is convenient: it may be much more accurate to talk of points along a public benefit/member benefit spectrum, of differences of degree rather than kind.

${ }^{5}$ Combining $501(c)(8)$ and 501 (c) (10); see Table 1.
} 
mankind; practical benevolence toward men in general; the disposition or active effort to promote the happiness and wellbeing of one's fellow-man." Most definitions and discussions of "philanthropy" focus on human behavior intended primarily to benefit people other than the agent and his or her immediate group (e.g., family, close friends, business associates).

\section{Origins and Functions of Mutual Benefit Organizations}

While this paper calls for more attention to current MBOs, studies of earlier MBOs provide an illuminating introduction. ${ }^{6}$ There is certainly danger of anachronism here. Although human beings have grouped together for various purposes since the beginning of humankind, clearly the social, economic, and cultural context of such associating has changed enormously, with the resultant need to be cautious in using the same terms to describe what may be very different realities in different settings. For instance, the term "voluntary" surely has different meanings in urban and rural settings, modern and medieval and ancient periods, and industrial and tribal cultures. But while there is need for caution in interpreting the

${ }^{6} \mathrm{Kropotkin}$ argues at length that mutual aid is a fundamental principle of both animal and human existence and development, and that in the process of evolution, mutual aid is at least as important as struggle and the survival of the fittest. "The mutual-aid tendency in man has so remote an origin, and is so deeply interwoven with all the past evolution of the human race, that it has been maintained by mankind up to the present time, notwithstanding all vicissitudes of history" (1972 [1902], p. 194). 
historical and anthropological data, there seems no excuse for ignoring it altogether.

Anthropologists have noted the existence of "voluntary associations" or "sodalities" (from the Latin sodalis, for "comrade" or "close friend") with many of the characteristics of MBOs as far back as the neolithic period, starting roughly in the seventh or eighth millennium B.C.' (Anderson, 1971; Banton, 1968; Lowie, 1948, pp. 294-316; Smith and Freedman, 1972, pp. 16$18,20-22,132-133)$. Many of these associations seem to have been essentially men's clubs and/or adults' groups and/or secretknowledge societies. There were also women's societies with their own secrets. Lowie (1948, p. 316) argues that the development of a primitive tribe was to some extent a function of the presence of associations: "By making cooperation a reality beyond the narrow confines of the blood tie they pave the way, in principle at least, for a wider integration, whether in the form of a state or of a supernatural religion."

The presence of associations is even more evident in primitive tribes making a transition to more complex socioeconomic tribal or intertribal systems or--more radically still--having to adjust to town or city culture, as in modern Africa. Indeed, one of the main functions of such tribal associations is, as much as possible, to re-create within the

\footnotetext{
${ }^{7}$ As Anderson (1971, p. 211) points out, "The process had no clear end. It lasted into our era. Neolithic settlers were still moving onto inhabited islands in Oceania as recently as circa A.D. 1000, when the Mari moved to New Zealand."
} 
town or city the tribal village with its customs and support systems :

[Voluntary associations] represent the newly arrived migrants' response to urban conditions. Belonging, in his rural home, to a compact group of kinsmen and neighbours, he has been used to a highly personal set of relationships. He knows of no other way of communal living than this and so to organize similar practices of mutuality is for him a spontaneous adjustment to his environment. (Little, 1965, p. 24)

Besides playing this conserving, traditionalist role, such associations also prepare tribe members to deal more effectively with their new environment:

- . urban life is characterized inter alia by a. specialization of function. Instead of being carried on by the kin group and the tribe, activities of the town are divided among a larger number of institutions [such as businesses, schools, churches and mosques, courts, and the policel. . . The voluntary association serves as an adaptive mechanism in relation to these new institutions by facilitating role segmentation. (Little, 1965, pp. 101-102) 
These urban-tribal associations also exhibit the beginnings of "philanthropic" behavior:

[The Ghanian associations' activities] include excursions and picnics; concerts, singing, dancing and drumming; religious talks and discussions, literacy classes, debates, and cinema shows; first-aid services; initiation ceremonies for new members; and the laying of wreaths on graves of former members. . . In addition, collections are made or money required for the various forms of assistance rendered to members, and for the help which more than half the societies studied extend to the wider public, especially the socially handicapped. Members take presents of money and in kind to hospitals and prisons and to other institutions where the inmates may be in need of advice or encouragement. (Little, 1965, p. 54, emphasis added)

Ancient China, Egypt, Greece, and Rome had merchants' associations, cooperative loan societies, associations for visiting the sick and burying the dead, religious cults, and club-like groups. The medieval period saw the widespread development of merchant and craft guilds, occupation-based groups which provided to their members many benefits beyond those that were directly work-related. For instance, "The French Eraternities (confréries) . . professed religious and charitable ends, celebrating holy services, aiding masters who 
were financially embarrassed, and attending to the funerals of the membership" (Lowie, 1948, p. 307). Confréries of winegrowers, originally formed for mutual support in bad crop years, took on general philanthropic activities such as supporting local hospitals and orphanages. The same was true in China;, where "merchant and craft guilds not only regulated business and exercised jurisdiction over their members, but also kept streets and drains in order, organized fire brigades, and attended to poor relief" (Lowie, 1948, p. 313).

The demise of the guilds in Europe and England opened the way for the "friendly societies" " which performed many of the functions that the guilds had (Gosden, 1974). The friendly societies can be traced back to at least the late 17 th century, and are mentioned in a 1697 essay by Daniel Defoe, in which he gives this definition: "a number of people entering into a mutual compact to help one another, in case any disaster or distress fall upon them." The early friendly societies were principally organized by workingmen in response to economic, social, and other needs. These workingmen's associations which originated in England and were later transplanted to the United States included such groups as the Independent Order of Oddfellows, the Ancient Order of Foresters, and the United Ancient order of Druids. As time went on, in both England and the United States, these groups became far more identified with the middle classes than with the

\footnotetext{
${ }^{8}$ Or, as they were sometimes called, "box clubs," after the boxes in which members put their donations.
} 
working classes, but it is worth noting that they originally began for essentially the same reasons that American immigrant and minority $\mathrm{MBO}$ segan, to create an alternative social insurance and welfare system for the lower classes.

American history sheds further light on the activities of voluntary associations including those we now term MBOs. In the 17 th and most of the 18 th centuries, population dispersion and colonial status discouraged associational activity, with the important exception of alternative religious groups (Schlesinger, 1964, pp. 24-50; Handlin and Handlin, 1961, pp. 89-112). But in the late $18 \mathrm{th}$ and $19 \mathrm{th}$ centuries, with the advent of political freedom, new constitutional and legal support for the right to associate, the rise of towns and cities, and the massive influx of immigrants, Americans created a wide variety of associations. ${ }^{9}$ In addition to the host-society and largely

\footnotetext{
${ }^{9}$ Not all Americans were enthusiastic about the rapid growth of associations. James Madison warned of the dangers of "factions" in No. 10 of the Federalist Papers ("By a faction, I understand a number of citizens, whether amounting to a majority or minority of the whole, who are united and actuated by some common impulse of passion, or of interest, adverse to the rights of other citizens, or to the permanent and aggregate interests of the community"). Henry Thoreau commented: "The American has dwindled into an odd Fellow, one who may be known by the development of his organ of gregariousness, and a manifest lack of intellect and cheerful self-reliance." Ralph Waldo Emerson sniffed: "At the name of a society, all my repulsions play, all my quilis rise and sharpen." Orestes Brownson growled: "Matters have come to such a pass, that a peaceable man can hardly venture to eat or drink, or to go to bed or to get up, to correct his children or to kiss his wife, without obtaining the permission and direction of some . . . society." And the nation's first President had, in his farewell address, condemned "all combinations and associations, under whatever plausible character, with the real design to direct, control, counteract, or awe the regular deliberation and action of the constituted
} 
upper-class-initiated philanthropic agencies to which nonprofit sector historians have given so much attention (e.g., the Red Cross, the YMCA, Jane Addams' Hull House, ${ }^{10}$ Dorothea Dix's mental health care work, private foundations, private universities, Community Chest and United Way), Americans created thousands of mutual assistance agencies for self-improvement, companionship, protection against sudden economic loss, protection against discrimination, and a decent burial.

Some of these organizations were what we would now call self-help groups. Especially on the rugged frontier and in the often depressing cities, one problem many people needed help with was alcohol abuse or, in the more straightforward language of the time, drunkenness. By 1835 there were 1.2 million members of the American Temperance Society in eight thousand local affiliates.

authorities."

${ }^{10}$ Chambers (1986, p. 431) points out that ethnic community centers and lodges served many of the same functions (perhaps more effectively) that settlement houses did, but have been relatively ignored by welfare historians:

They gathered to sing and dance and feast, to play and to pray, to celebrate and to affirm the unique cultural heritage which each group cherished. In their own halls, with their own kind, they could feel at home as they rarely could in a settlement house, however affirming it might be of the integrity and value of old world cultures. There were classes in English and civics, special clubs for mothers and boys and girls, forums to debate controversial issues, programs in nutrition and hygiene, classes in crafts and arts, well-baby clinics, dramatic readings, and festivals. The wonder is that welfare historians have paid so little attention. Published studies of settlement houses and biographies of their founding mothers (and fathers) abound, but the integration of immigrant and black fraternal and social centers into the larger story of welfare history is still to be accomplished. 
These were clearly "mutual benefit" or "mutual assistance"

groups: members helped each other conquer the temptation of demon rum. Yet these groups also gave assistance to other victims of alcohol, especially the spouses and children of alcoholics, and worked to persuade the society generally to refrain from alcohol.

Most MBOs focussed on the members' economic concerns. Immigrants and minorities established fraternal organizations to find jobs, find apartments, insure against sickness or injury, and provide for a decent burial.11 It is important to note that the great majority of 19 th century MBOs were created by lowerincome and often discriminated-against groups that were far more vulnerable to financial vicissitudes than were members of the middle and upper classes. Neither the government nor hostsociety charity provided a "safety net" for such people, ${ }^{12}$ who often could not get adequate assistance from established financial institutions. For instance, in the latter part of the

\footnotetext{
${ }^{11}$ Concern for an adequate and dignified burial (including the presence of mourners) is perhaps the most constant theme in MBO activity throughout history--in primitive tribes, in ancient civilizations, in the period of the guilds and the friendly societies, and in more recent fraternal organizations. "Funeral ceremonies became a central part of most organizations and members could rest secure in the knowledge that they would be assured a decent burial" (Franco, 1986, p. 73). "...the main aim of the members of the societies was to seek insurance against the disgrace of a pauper funeral" (Gosden, 1974, p. 115).

$12 "$. . . the mutual aid association provided a degree of security against the hazards of urban life and industrial work prior to the development of 20 th century welfare capitalism and government insurance. Their basic function was to provide a measure of security in case of sickness and above all at the time of death." (Records, 1981, p. 3)
} 
19 th century, blacks were designated by the Actuarial Society of America as one of 98 "special risk" categories, simply because of their race (Records, 1981, p. 31). These ethnic and minority fraternal associations were certainly "mutual benefit" in intent and operation, but their net effect was to promote the general welfare of dispossessed groups in the absence of government programs and in the face of indifference or discrimination from the upper classes. The Mexican American mutualistas (Camarillo, 1991; Hernández, 1983; Rivera, 1984), mutual assistance groups in the African American community (Babchuk and Thompson, 1962; Kuyk, 1983), the Ancient Order of Hibernians and the Sons of Italy and B'nai B'rith and the Ukrainian Workingmen's Association, in taking care of their own, turned potential recipients of philanthropy into agents of human welfare. ${ }^{13}$

\footnotetext{
${ }^{13}$ It is easy to grasp the philanthropic significance of the economic benefits (e.g., sickness and death benefits) of ethnic and minority fraternal organizations. A less tangible matter is the philanthropic significance of the psychological benefits of such groups. Ethnic, minority, and host-society fraternal organizations all included elements whose main purpose was to enhance the self-concept, self-confidence, and sense of identity of the members. Practices that later became appropriate objects of ridicule began as poignant efforts on the part of low-status persons to find and maintain a sense of self-worth, through connection with the past, ritual, mystery, secrecy, and impressive names. A member of the Ancient Order of Foresters was taught to feel identity with Robin Hood, and was told that Adam was the first Forester. Members of the Modern Woodmen of America stirred to the motto of "Roman dignity and forest freedom." The Mason's tool symbols evoked a simple, honorable profession, uncorrupted and aimed at excellence. Poor, despised Irish and Italian Catholics could become knights [of columbus] as of old. A common laborer who belonged to the United Ancient order of Druids was transported into the misty past of power, religion, and earthiness. The societies didn't meet in ordinary halls, they met in "lodges" and "courts." And the uniforms and titles were magnificent. Garrison Keillor tells of growing up in the
} 
These ethnic and minority associations paralleled and to some extent were stimulated by fraternal organizations among the more established groups in American society, particularly those of a British or Northern European origin; those with more relationship to mainline Protestantism than to Judaism, Catholicism, or counter-cultural Protestantism; and those representing rural, small town, and urban middle class rather than urban working class social standing. These unhyphenated Americans joined a wide variety of societies, lodges, and fraternal associations, such as the Masons, the Elks, the Moose, the Beavers, the Oddfellows, the Foresters, and so forth. ${ }^{14}$

fictional Lake wobegon and, as a boy from a severely plain Protestant family, watching with awe and secret longing as the Knights of columbus marched by with their crimson capes and glistening swords. The head of such a society became a Grand Knight, or an Imperial Wizard, or the Most Supreme Grand Chancellor of the United States (Hill, 1892, p. 384), heady stuff for a man who didn't always think he was sufficiently respected by his wife, much less his employer. Nor were the glories of such organizations limited to men. One women's group was titled the Original Grand United Order of the Totally Abstinent Daughters of the Phoenix. Although they didn't use the term, these societies were concerned with psychological and social as well as economic benefits. It is significant that such practices didn't fall into wide-scale disrepute until the members of these fraternal organizations had moved into the middle and upper classes and were, in some cases, doing their best to keep out lower-class, lower-status persons.

${ }^{14}$ Oscar and Mary Handlin (1961, p. 97) point out that it is a mistake to separate too sharply the associative behavior of immigrants and internal migrants:

The immense proliferation of associations was in part a product of the mid-nineteenth-century fragmentation of the American community and, in part, a result of the increased ethnic diversity of the population produced by internal and foreign migration. Needs which could no longer be met by a whole community acting through the state were now satisfied by narrower voluntary associations. Although paradoxically, 
Both immigrant and host-culture fraternal organizations periodically acted to benefit people beyond their membership ranks. The societies collected and donated money for various charitable causes, such as war relief, disaster relief, and the care of orphans, the aged, and the handicapped. Such gifts were most frequently directed to affiliated persons--e.g.. a Polish organization donating to Polish war victims in Europe--but the charity often went beyond affiliation--e.g., donations to a local Shriners' hospital. Also, in ways perhaps difficult for post1960 s generations to comprehend, the fraternal associations were quite serious about moral and intellectual self-improvement partly as a means to improve society. The organizational Iiterature of these groups is replete with quasi-religious references to self-improvement, and frequently the ultimate objective is clearly not personal advancement but societal benefit.

Some MBOs became transformed into social and political advocacy groups. We have seen one important example, the temperance movement. Another example was the order of Patrons of Husbandry, more commonly known as the Grange movement. This farmers' MBO, founded in 1867, was highly successful in combatting the poverty and isolation that afflicted many of the nation's agricultural workers. By 1875 there were 800,000 Grange

the few existing formal studies have dealt with the problems of the foreign-born, the behavior of natives--the Yankees for example--as they moved to the west and to the cities was remarkably similar. 
members in 20,000 local chapters. One of the innovative and successful Grange practices was to allow women to become full members. For farmers' wives, who often led lives of extreme isolation and drudgery, the Grange meetings, picnics, lectures, entertainments, and political activities were a godsend. Grange chapters were extensively involved in philanthropic work affecting farmers and their communities. Similarly, the workingmen's associations which often started as economic security MBOs developed into labor unions, powerful mechanisms not only for advancing the interests of worker-members but also for promoting public education, child labor laws, anti-pollution measures, and other broad societal issues. ${ }^{15}$

Other occupation-related MBOs developed during the 19 th and early 20 th centuries, including business leagues, trade associations, and professional associations such as the American Statistical Association (1839), the American Ethnological Society (1842), the American Medical Association (1847), the American Society of Engineers and Architects (1852), the American Entomological Society (1859), and the American Bar Association (1878). These were clearly MBOs in that their main purpose was to provide a variety of benefits to their members, but they also performed and continue to perform public benefit functions, including research and development, education and training,

${ }^{15}$ Since the work of labor unions, including their broader societal and philanthropic activity, is a far more developed field of literature, it will not be discussed here. Still, it is important to note in the union movement the same connection of mutual and public benefit that we see in so many other MBOs. 
publications and conferences for members and for the general public, and scholarship and fellowship programs. The licensing, accreditation, professional education, research, and other activities of these MBOs have had incalculable effect on the development of health care, educational, scientific, commercial, and other general societal functions. As one study of the societal value of such associations said:

. . consumers of professional services, virtually all of whom lack adequate information to judge the ability and performance of a practitioner, are assured the practitioner has met standards for education and training, performance, and ethics established by those who do have adequate information to make such judgements, namely, the practitioner's peers. (Value, 1990, p. 23)

\section{Current Dimensions of Mutual Benefit Organizations} The following table presents the Internal Revenue Service's most recent statistics on the types and numbers of nonprofit MBOs in the United States. The table includes information on all "exempt organizations" except 501(c)(3) and 501(c)(4) nonprofits--defined as the "independent sector" by the national organization of that name, and accepted by most nonprofit sector 
scholars as the "charitables" or public benefit nonprofits as distinguished from the nonphilanthropic, noncharitable MBOs. ${ }^{16}$

${ }^{16}$ While there is no question as to whether 501 (c) (3) organizations should be classified as "charitable, " there is some difference of opinion and statistical usage regarding the classification of 501 (c) (4) organizations--at least some of them (e.g., see footnote 1 of this paper). We have adopted the view, consistent with Independent sector's statistical reporting, that 501 (c) (4) organizations should be classified as philanthropic, public benefit nonprofits. 
Table 1

Number of Non-501(c)(3) \& (4) Active Exempt Organizations in 1989

$501(c)$

(1) Corporations organized under act of Congress 9

(2) Titleholding corporations for exempt orgs. 6,090

(5) Labor, agriculture, horticulture orgs. 72,689

(6) Business leagues, chambers of commerce, etc. 63,951

(7) Social and recreation clubs 61,455

(8) Fraternal beneficiary societies 99,621

(9) Voluntary employees' beneficiary societies 13,228

(10) Domestic fraternal beneficiary societies 18,432

(11) Teachers' retirement funds 11

(12) Benevolent life insurance associations 5,783

(13) Cemetery companies 8,341

(14) Credit unions 6,438

(15) Mutual insurance companies 1,118

(16) Corporations to finance crop operation 17

(17) Supplemental unemployment benefit trusts 674

(18) Employee funded pension trusts 8

(19) War veterans' organizations 26,495

(20) Legal service organizations 200

(21) Black lung benefit trusts 22

(22) Multi-employer pension plans 0

(23) Veterans associations (created before 1880) 0

(24) Trusts described in section 4049 of ERISA 0

(25) Holding companies for pensions, etc. 43

501 (d) Religious and apostolic organizations 94

501 (e) Cooperative hospital service orgs. 79

501 (f) Coop. service orgs. of educational orgs. 1

$501(\mathrm{k})$ Treatment of certain orgs. providing child care 7

521 (a) Farmers' cooperative associations 2,279

Taxable farmers' cooperatives . 3,295

Nonexempt charitable trusts $\quad 42,314$

$\begin{array}{ll}\text { Total } & 432,694\end{array}$

Source: Internal Revenue Service, Annual Report, 1989, p. 54, Table 20 .

As with all "Official" statistics on the nonprofit sector, the data in Table 1 need to be interpreted with some caution. The statistics include only groups that have applied for and 
received tax-exempt status from the Internal Revenue Service. Some groups do not choose to do so or are not required to do so. For instance, Jacobs and Goodman (1989) estimate that there are a few hundred thousand self-help groups in the U.S.; clearly very few of these have registered as MBOs. Smith (1989, pp. 314-315), using a ratio he developed earlier for projecting the number of associations per thousand population in U.S. cities and towns, estimates that there may be as many as 7.32 million voluntary associations (MBOs and all other kinds) in the country. The ratio was derived from actual counts of voluntary associations in several community studies. The wide discrepancy between this. projection and Independent Sector's estimate of 1.4 million nonprofits of all types is probably due to the larger figure's inclusion of (a) unincorporated groups and (b) subunits of national organizations, such as the Boy scouts, that have only one IRS identification number. With these caveats, Table 1 gives some idea-probably a very conservative one--of the number of MBOs in the United States.

\section{Studying the Philanthropic Dimensions of MBOS}

Nonprofit sector representatives have argued since the Filer Commission Report of the mid 1970s that even though nonprofits constitute only 5-10\% of the American GNP and workforce, this figure is still considerable and therefore nonprofits should be taken more seriously and studied more carefully. This paper makes the analogous argument that even though MBOs represent only 
about $10 \%$ of the economic and personnel activity of the nonprofit sector (Rudney, 1987, p. 55), they should not be ignored by nonprofit sector scholars, as has largely been the case. The implied or stated reason for ignoring MBOs is that they are not charitable, not philanthropic, not part of the "independent" sector. Yet, as we have seen, even this proposition cannot stand unqualified, much less the idea that MBOs are unworthy of study in their primary, member-benefit, aspects. Historical, anthropological, sociological, and political science analyses show clearly that MBOs, while primarily oriented to providing specific benefits to members, also include--not just rarely but typically--activities that are "philanthropic" in the traditional ${ }^{17}$ sense of that word. Further, the member-directed activities of some MBOs (e.g., immigrant and minority fraternal organizations) have helped people whose social, economic, and psychological needs were not being met by official welfare and philanthropic agencies. Finally, we have argued that MBOs have occasionally evolved into or created philanthropic, publicbenefit organizations and therefore should be studied as a source of organized charity.

With this framework in mind, we can now turn to specific strategies for studying the philanthropic dimensions of MBOs.

\footnotetext{
${ }^{17}$ And perhaps somewhat narrow. Nonprofit sector scholars must face the possibility that "philanthropy" may be to some extent a classist term, describing the activities of the haves helping the have-nots, while the activities of poor people helping each other are described as "mutual benefit" and, by implication, somewhat less worthy of attention and respect.
} 
Member-directed benefits. Direct member benefits cannot be called "philanthropic" in the fundamental sense of the word, no matter how needy the recipients of these benefits. An ethnic fraternal organization getting a job for a starving immigrant may be emotionally and socially a different reality from an exclusive golf club providing a new business contact for a millionaire, but conceptually they are the same: MBOs providing economic benefits to members. However, some member-directed activities le.g., visiting the sick, burying the dead, caring for members' aged parents and orphaned children) may play an important role in generating philanthropic activities or shaping philanthropic attitudes and values on the part of the members. Ukrainians who have through their MBO helped a family through the pain of a suicide become more able to respond to an Italian or Jewish neighbor facing the same tragedy. MBOs are need-based: they come into existence to meet the needs of some group. While some needs (e.g., endogamous marriage, ethnic- or nationality-based cultural appreciation) of their very nature tend to keep group members isolated, other needs (disaster relief, war relief, care for mentally retarded children) of their very nature draw group members out of their group toward other people experiencing the same problems. ${ }^{18}$

\footnotetext{
${ }^{18}$ Kropotkin (1972 [1902], p. 232) gives the example of lifeboat associations on the English coast, essentially MBOs set up by fishermen to assist each other in bad weather. "The crews consist. . . of volunteers, whose readiness to sacrifice their lives for the rescue of absolute strangers to them is put every year to a severe test; every winter the loss of several of the bravest among them stands on record."
} 
Non-member-directed activities. Many MBOs include philanthropic activities in their bylaws, mission statements, organizational goals, and actual behavior. One fruitful area of research would be to analyze the stated goals of MBOs with regard to charitable practices. A useful beginning can be found in Records of Ethnic Fraternal Benefit Associations in the United States (1981, pp. 47-159), which provides a guide to the organizational records of 117 ethnic fraternal benefit associations. Schmidt (1980) presents listings and short sketches of 461 fraternal organizations, including considerable information on the philanthropic activities of these organizations. The Encyclopedia of Associations (1991) gives brief descriptions of thousands of MBOs and other associations. Most states require MBOs and other nonprofits to file articles of incorporation and bylaws with a state agency, and MBOs above $\$ 25,000$ a year are required to file annual financial and program reports with at least the IRS and often also a state agency. These sources provide dozens of examples of the external activities of ethnic fraternal benefit associations: scholarships and student loan programs; aid to camps, libraries, archives, hospitals, churches, museums, schools, and colleges; support of institutions for the blind, orphans, retarded children, handicapped, aged, war victims, and substance abusers; contributions to medical research; disaster relief; international relief; and blood donations. 
Data on the community service activities of MBOs would provide another view of the topic. A recent study indicated that 10 percent of trade associations and 23 percent of professional associations participated in community service activities (Value, 1990, p. 102). "Service clubs" such as Rotary, Kiwanis, Lions, and Elks often have community service projects, as do chambers of commerce and other business-related MBOs.

Gathering new data from a sample of MBOs within a limited geographic area would be another useful approach and would enable researchers to seek a wide variety of descriptive documentation: articles of incorporation, bylaws, mission statements, brochures, newsletters and other publications, minutes of meetings, budgets, annual reports, and the like. Survey questionnaires and interviews with agency board members, staff, and members would add important information. In a few cases direct researcher observation of MBO activity (board meetings, staff work, volunteer work) would be feasible. All these are potential sources for analyzing the philanthropic dimensions of MBOs.

Generational studies. Historical literature on MBOs suggest that at least some of them make major changes in their mission and work over time. Such transformations have been studied in public benefit organizations--e.g., Sills' (1957) classic study of the March of Dimes. There is need for similar research on MBOs. Not only do MBOs often include philanthropic activities from the outset, many of them evolve into more distinctly 
philanthropic behavior as time goes on. Thus, a German Jewish MBO might begin (e.g., in the mid 19th century) working only with German Jews, later add Russian and Polish Jewish immigrants, later still add Jews in the state of Israel, and finally include non-Jews (e.g., students supported by the United Negro College Fund). A similar pattern has been evident in many Catholic educational, health care, and social service institutions. At first their scope was exclusively Catholic land often exclusively Irish or Italian or Polish Catholic), but through a series of iterations they found themselves serving large numbers of nonCatholics. The parochial schools in central city areas, now populated largely by non-Catholic blacks, form only one example. As MBO members become less needful of immediate assistance, beneficial activity starts to turn outward.

\section{Summary and Conclusions}

Many historians, political scientists, sociologists, and anthropologists have analyzed MBOs while discussing the more general phenomenon of voluntary action. Nonprofit sector specialists have generally ignored this large and interesting part of the nonprofit sector. There seems no reason to continue such exclusion, even on grounds of philanthropic focus. MBOs clearly contain not only member-directed but also philanthropic activity. Further research might show even more philanthropic activity than is now evident. There are many different ways in 
which the question of the philanthropic dimensions of MBOs might be pursued by scholars. This is a potentially rich area of nonprofit sector research, and it has the advantage of building on a substantial base of theory and research on voluntary associations from sociology, political science, and other disciplines. 


\section{References}

Adams, James L. Voluntary Associations: Socio-Cultural Analyses and Theological Interpretation. Edited by J. Ronald Engel. Chicago: Exploration Press, 1986.

Anderson, Robert T. "Voluntary Associations in History." American Anthropologist, Vol. 73 (February 1971): 209-222.

Babchuk, Nicholas, and Thompson, Ralph V. "The Voluntary Associations of Negroes." American Sociological Review, 27 (October 1962): 647-655.

Banton, Michael. "Voluntary Associations: Anthropological Aspects." In David L. Sills (ed.), International Encyclopedia of the Social Sciences. Vol. 16. New York: Macmillan, 1968.

Ben-Ner, Avner, and Van Hoomissen, Theresa. "The Growth of the Nonprofit Sector in the 1980s: Facts and Interpretations." Nonprofit Management and Leadership, 1, 2 (Winter 1990): 99-116.

Biddle, Jeff E. "Who Benefits from the Activities of America's Religious Congregations?" In Charles Clotfelter, Who Benefits? The Distributional Consequences of the Nonprofit Sector. Chicago: University of Chicago Press, 1992 (forthcoming).

Blau, Peter M., and Scott, W. Richard. Formal Organizations: A Comparative Approach. San Francisco: Chandler, 1962.

Camarillo, Albert. "Mexican Americans and Nonprofit Organizations: An Historical Overview." In Herman E. Gallegos and Michael O'Neill, Hispanics and the Nonprofit Sector. New York: Foundation Center, 1991.

Chambers, Clarke A. "Toward a Redefinition of Welfare History." Journal of American History, 73, 2 (September 1986): 407-433.

Clawson, Mary Ann. Constructing Brotherhood: Class, Gender, and Fraternalism. Princeton, N.J.: Princeton University Press, 1989.

Derrickson, Margaret C. The Literature of the Nonprofit Sector: A Bibliography with Abstracts. Vol. 1. New York: Foundation Center, 1989.

Derrickson, Margaret C., and Kurdylo, Kevin M. The Literature of the Nonprofit Sector: A Bibliography with Abstracts. Vol. 2. New York: Foundation Center, 1990.

Encyclopedia of Associations. 20th ed. Detroit: Gale Research, 1991. 
Ferguson, Charles w. Fifty Million Brothers. New York: Farrar and Rinehart, 1937.

Franco, Barbara. Fraternally Yours: A Decade of collecting. Lexington, Mass.: Scottish Rite Masonic Museum of Our National Heritage, 1986.

Gosden, P. H. J. H. Self-Help: Voluntary Associations in 19thCentury Britain. New York: Barnes and Noble, 1974.

Handlin, Oscar, and Handlin, Mary. The Dimensions of Liberty. Cambridge, Mass.: Belknap Press of Harvard University Press, 1961.

Hernández, José A. Mutual Aid for Survival: The Case of the Mexican American. Malabar, Fl.: Krieger, 1983.

Hill, Walter B. "The Great American Safety-Valve." The Century, $44(1892): 383-384$.

Hodgkinson, Virginia A., and Weitzman, Murray S. Dimensions of the Independent Sector: A Statistical Profile. Washington, D.C.: Independent Sector, 1984.

Jacobs, Marian, and Goodman, Gerald. "Psychology and Self-Help Groups: Predictions on a Partnership." American Psychologist, 44 (1989): $1-10$.

Kropotkin, Peter. Mutual Aid: A Factor of Evolution. New York: New York University Press, 1972 [1902].

Kuyk, Betty M. The African Derivation of Black Fraternal Orders in the United States. Cambridge, England: Cambridge University Press, 1983 .

Layton, Daphne N. Philanthropy and Voluntarism: An Annotated Bibliography. New York: Foundation Center, 1987.

Little, Kenneth L. West African Urbanization: A Study of Voluntary Associations in Social Change. Cambridge, England: Cambridge University Press, 1965.

Lowie, Robert H. Social Organization. New York: Rinehart, 1948.

Powell, walter W. (ed.). The Nonprofit Sector: A Research Handbook. New Haven, Conn.: Yale University Press, 1987.

Records of Ethnic Fraternal Benefit Associations in the United States: Essays and Inventories. St. Paul, Minn.: Immigration History Research Center, 1981. 
Revised Model Nonprofit Corporation Act. Subcomittee on the Model Nonprofit Corporation Law of the Business Law Section, American Bar Association, Michael C. Hone, Reporter. Clifton, N.J.: Prentice Hall Law and Business, 1988.

Rivera, Jose A. Mutual Aid Societies in the Hispanic Southwest: Alternative Sources of Community Empowerment. Albuquerque, N.M.: Southwest Hispanic Research Institute, University of New Mexico, 1984 .

Rudney, Gabriel. "The Scope and Dimensions of Nonprofit Activity." In Walter W. Powell (ed.), The Nonprofit Sector: A Research Handbook. New Haven, Conn.: Yale University Press, 1987 .

Schlesinger, Arthur M. Paths to the Present. Boston: Houghton Mifflin, 1964 .

Schmidt, Alvin J. Fraternal Organizations. Westport, Conn.: Greenwood, 1980 .

Sills, David L. The Volunteers: Means and Ends in a National Organization. Glencoe, Ill.: Free Press, 1957.

Smith, Constance, and Freedman, Anne. Voluntary Associations: Perspectives on the Literature. Cambridge, Mass.: Harvard University Press, 1972.

Smith, David H. "Four Sectors or Five? Retaining the Membership Sector." In Worn Paths and Unbroken Trails: The Volunteer Movement at the Turning Point. Proceedings of the 1989 Conference of the Association of Voluntary Action Scholars. Walla Walla, Wash.: Inland Printing and MBA Publishing, [1989].

Stevens, Albert. Cyclopedia of Fraternities. New York: Hamilton Printing and Publishing Co., 1899.

The Value of Associations to American Society: A Report by the Hudson Institute. Washington, D.C.: American Society of Association Executives, 1990. 
